\title{
Estimation of Livestock Methane Emissions in the Extensive Crop-Livestock Farming Areas of Bale Highland, Oromia, Ethiopia
}

\author{
Abstract: \\ Girma Defar, Department of Animal and Range Sciences, Madda Walabu University, P.O. Box 243 \\ Ashenafi Mengistu, Department of Animal Production, Addis Ababa University, P.O. Box 34 \\ Gebreyohannes Berhane, Department of Animal Production, Addis Ababa University, P.O. Box 34
}

The study was conducted in the potential mixed farming areas of Bale highland to estimate livestock methane emissions. Using multi-stage purposive sampling, 156 households of the three wealth groups were selected based on their livelihood assets as described under methodology. Structured questionnaires, focus group discussions, key informants interview and field visits were the employed methods during the study. Feed nutrient balance was estimated based on the demand and supply while the livestock methane emissions were estimated according to the IPCC guidelines. Descriptive statistics and one-way ANOVA tests were used to analyze the data. Cattle were the dominant (84.25\%) livestock owned by the households. The estimated enteric $\mathrm{CH}_{4}$ emission rate from mature cattle, growing cattle, sheep $>1$ year, sheep $\leq 1$ year, horse and donkey were significantly $(P<0.001)$ higher for the better wealth group while mature cattle (69.78\%) shared the highest rate. Though, higher emission rates credited to the large number of animals in the area, cattle stay crucial to the livelihoods of the households, beside the major sources of $\mathrm{CH}_{4}$. In conclusion, the estimated $\mathrm{CH}_{4}$ emissions should be focus areas of interventions. Therefore, proper husbandry and quality feed supply and promotion of farm level livestock technologies should be practiced wisely to increase productivity and protect the environment from emissions of the livestock sector.

Key words: Bale highlands; Livestock; Methane emissions; Mixed farming

\section{INTRODUCTION}

Ethiopia is the home to the Africa's largest livestock population standing eighth from the world (Rich et al., 2008) and is the principal exporter of live animals and meat to the Middle East (Gebremariam et al., 2010) being endowed with the diversified species and breeds of animal. According to the recent CSA (2016) report, the country is endowed with 57.8, 28.0, 28.6, 2.1, 7.9, 0.4, 1.2 and 60.5 million heads of cattle, sheep, goat, horse, donkey, mule, camel and chicken, respectively. From the total livestock population of the country, more than $75 \%$ inhabited the mixed farming areas (Deressa et al., 2010; FDRE-CRGE, 2011). In the country, the 
sector is gradually booming due to increasing global and domestic demand for their products linked to population and economic growth (IGAD, 2011).

It has been reported that farm animals from mixed farming contribute to climate change mainly through greenhouse gas emissions and natural resource degradation (Herrero et al., 2008). Because livestock and environment are closely related as livestock depends on land and water resources while livestock emits pollutant gases to environment. These let the sector recently to be blamed for significant contributions to the global climate (IPCC, 2006; CDR, 2011). Researchers underpin those mixed farming areas livestock diets were composed of grazing, crop residues, cut and carry, concentrates and opportunistic feeds. These dietary differences were important for the disparity in methane $\left(\mathrm{CH}_{4}\right)$ emissions within the system. For example, an average figure of $32 \mathrm{~kg} \mathrm{CH}_{4}$ per TLU per year for African ruminants is high compared to the low production performance of the animals (Herrero et al. 2008).

In Ethiopia, CDR (2011) reported that the livestock sector offers a potential $\mathrm{CH}_{4}$ emission abatement, though the type of production systems and feed resources used for different production systems not mentioned separately. Hence, estimation of emissions from livestock in smallholder mixed farming system helps to generate baseline information that could be an input to the national emission inventory of the sector and subsequent mitigation strategy development. However, no attempt has been made to estimate $\mathrm{CH}_{4}$ emissions from the livestock in the mixed farming system areas of Ethiopia in particular to Bale. Bale highland is one of the potential mixed farming areas of Ethiopia where crop-livestock farming is the predominant practice with the existing intricate problems. Provided that, livestock husbandry practices and feed resources are dynamic; livestock $\mathrm{CH}_{4}$ emission assessment of area specific data are pertinent for the further actions (Jo et al., 2015). In addition, the situation constrained by the factors that limit estimation of emissions from the sector due to lack of to date temporal and spatial data on livestock population trend, production type and feed resources (Silvia and Deborah, 2012). Therefore, looking at existing livestock population of the area and $\mathrm{CH}_{4}$ emission interrelationships across the wealth groups is vital to explore baseline information that could be used for the national greenhouse gas inventory and future design of improved livestock production by the policy makers and livestock development intervention actors. With this consent, the study was initiated to estimate $\mathrm{CH}_{4}$ emissions from the livestock under the prevailing production system. 


\section{METHODOLOGY}

The study was conducted in Bale Zone of Oromia National Regional State, Southeast Ethiopia. Recent demographic report revealed that the human population of the Zone is estimated at $1,616,061$ of which, $87.3 \%$ live in the rural area (Bale Zone BoFED, 2012). The study area was situated at the highland altitude with mean annual rainfall of $860.00 \mathrm{~mm}$. The average minimum and maximum daily temperatures were $9.4 \mathrm{o}^{\mathrm{c}}$ and $25.2 \mathrm{o}^{\mathrm{c}}$ (NMA Bale branch unpublished data). The study area has large livestock resources, since the livelihoods base is livestock herding and cultivation. The major livestock species reared by the inhabitants include cattle, sheep, donkey, horse and chicken (CSA, 2016). The three districts used for this study were among the first few potential mixed farming districts of the Zone known for the extensive cultivation and raising high livestock population (Chibsa and Ta'a, 2009).

Sampling procedure: Three potential mixed farming (cereal-cattle dominant) districts were purposively selected from the nine highland mixed farming districts based on cropland cover and livestock population potential. Nine kebeles were randomly selected from the fifty-five croplivestock farming kebeles of the study districts. The households (HHs) were stratified into three different wealth groups on the basis of their livelihoods asset (livestock and land) possessed and capacity of the farmers to satisfy basic needs of their family that made in consultation with development agents, district experts and community representatives (Eba, 2012). The groups were better wealth ( $\geq 4.25$ hectare land, $>15$ TLU); medium wealth (2.25-4.25 hectare land, $>5$ and $\leq 15 \mathrm{TLU})$, and low wealth $(\leq 2.25$ hectare land, $\leq 5 \mathrm{TLU})$. A total sample size of $156 \mathrm{HHs}$ was used to represent study population (Arsham, 2005).

Data collection: A survey using pretested semi-structured questionnaires was carried out a face to face interview in 2015 which covered subjects like livestock holding, herd composition and major feeds available in the area. Nine enumerators who were working as development agents in the sample kebeles were selected and trained on the primary data collection methods under the close supervision of the researcher. A single focus group discussion comprising 9-13 people, who drawn from farmers of different wealth groups, sex, farming experience and development agents were conducted in all nine kebeles by the researcher. 


\section{Estimation of livestock nutrient requirement}

The study HHs livestock population converted to tropical livestock unit (TLU). The animal specific TLU conversion factors used for ox/bull, cow, heifer, steer, calf, sheep, horse and donkey were $1.1,0.8,0.5,0.6,0.2,0.1,0.8$ and 0.5 , respectively as recommended by (Jahnke, 1982; Gryseels, 1988). The daily DM demand for the standard TLU of $250 \mathrm{~kg}$ at $2.5 \%$ of the body weight, which is equivalent to 6.25 per day or $2280 \mathrm{~kg}$ per year suggested by (Jahnke, 1982) was used. The ME and DCP maintenance requirement for the livestock were estimated according to the daily average recommendations suggested by Kearl (1982).

\section{Estimation of enteric methane emission}

Enteric $\mathrm{CH}_{4}$ emission estimation requires definitions of the livestock categories: species, herd structure and existing population in the study area. Hence, cattle divided into growing and mature type based on average live body weight of $200 \mathrm{~kg}$ and $280 \mathrm{~kg}$, respectively, sheep into ( $\leq$ 1 year and $>1$ year) and equines into (horse and donkey). The separation was done in line with the CDR (2011) and IPCC (2006) recommendations which has stated as "it is good practice to classify existing livestock population into subcategories". With respect to animal productivity, the local cattle were used for more than one purpose (milk, meat and draught). The energy used for draught was estimated using 8 hours heavy work per day (IPPC, 2006) while emission factors were developed according to the dual purpose cattle of the developing countries and previous research reports (CDR, 2011).

Emission from enteric fermentation of the ruminant animals ( $\mathrm{kg} \mathrm{CH}_{4}$ per head/year) is a function of feed digestibility (i.e. the percent of GE intake that is metabolized) (Opio et al., 2013). An enteric $\mathrm{CH}_{4}$ conversion factor: $\mathrm{Y}_{\mathrm{m}}\left(\%\right.$ of $\mathrm{GE}$ converted to $\left.\mathrm{CH}_{4}\right)$ was used to calculate $\mathrm{CH}_{4}$ emission factors (EF) from ruminant enteric fermentation. The enteric $\mathrm{CH}_{4} \mathrm{EFs}$ for horse and donkey 18 and 10 ( $\mathrm{kg} \mathrm{CH} \mathrm{CH}_{4}$ per head/year), respectively were adopted from Tier 1 of the developing countries (IPCC, 2006). The Tier 2 approach was applied to calculate the enteric $\mathrm{CH}_{4}$ emissions due to sensitivity to the diet composition and relative importance of enteric $\mathrm{CH}_{4}$ to the total GHG emissions from cattle and sheep (IPCC, 2006).

$\mathrm{EF}=\frac{\mathrm{GE} *\left(\frac{\mathrm{Ym}}{100}\right) * 365}{55.65}$ 
Where: $\mathrm{EF}=$ emission factor $\left(\mathrm{kg} \mathrm{CH}_{4}\right.$ head $\left.^{-1} \mathrm{year}^{-1}\right)$,

$\mathrm{GE}=$ gross energy requirement $\left(\mathrm{MJ}\right.$ head $\left.^{-1} \mathrm{day}^{-1}\right)$,

$\mathrm{Y}_{\mathrm{m}}=\mathrm{CH}_{4}$ conversion factor (\% of $\mathrm{GE}$ in the feed converted to $\left.\mathrm{CH}_{4}\right)$ and

The factor $55.65\left(\mathrm{MJ} / \mathrm{kg} \mathrm{CH}_{4}\right)=$ the energy content of $\mathrm{CH}_{4}$.

In order to calculate the emissions, first need to estimate the value the gross energy (GE) requirement using equation 2 below.

$\mathrm{GE}=\left[\frac{\left(\frac{N E m+N E a+N E l+N E w+N E p}{R E M}\right)+\frac{N E g}{R E G}}{\frac{D E \%}{100}}\right]$

$\mathrm{GE}=$ gross energy $(\mathrm{MJ} / \mathrm{day})$,

$\mathrm{NE}_{\mathrm{m}}=$ net energy required by the animal for maintenance $(\mathrm{MJ} /$ day $)$,

$\mathrm{NE}_{\mathrm{a}}=$ net energy for animal activity (MJ/day),

$\mathrm{NE}_{\mathrm{g}}=$ net energy needed for growth (MJ/day),

$\mathrm{NE}_{1}=$ net energy for lactation $(\mathrm{MJ} /$ day $)$,

$\mathrm{NE}_{\text {work }}=$ net energy for work $(\mathrm{MJ} /$ day $)$,

$\mathrm{NE}_{\mathrm{p}}=$ net energy required for pregnancy $(\mathrm{MJ} /$ day $)$,

$\mathrm{REM}=$ ratio of net energy available in a diet for maintenance to digestible energy consumed,

$\mathrm{REG}=$ ratio of net energy available for growth in a diet to digestible energy consumed, $\mathrm{DE} \%=$ digestible energy expressed as a percentage of gross energy.

Table 1 . The formulae used to estimate different forms of net energy used by the animal

\begin{tabular}{|c|c|c|}
\hline S.N. & Type of energy required & Model used to estimate the required energy \\
\hline 2.1 & Net energy for maintenance & $\mathrm{NE}_{\mathrm{m}}=\mathrm{Cf}_{\mathrm{i}} *(\text { weight })^{0.75}$ \\
\hline 2.2 & Net energy for activity & $\mathrm{NE}_{\mathrm{a}}=\mathrm{C}_{\mathrm{a}} * \mathrm{NE}_{\mathrm{m}}$ \\
\hline 2.3 & Net energy for growth & $\mathrm{NE}_{\mathrm{g}}=22.02 *\left(\frac{B W}{C * M W}\right)^{0.75} * \mathrm{WG}^{1.097}$ \\
\hline 2.4 & Net energy for work & $\mathrm{NE}_{\mathrm{w}}=0.1 * \mathrm{NE}_{\mathrm{m}} *$ working hours \\
\hline 2.5 & Net energy for pregnancy & $\mathrm{NE}_{\mathrm{p}}=\mathrm{C}_{\text {pregnancy }} * \mathrm{NEm}$ \\
\hline 2.6 & Sheep net energy of lactation & $\mathrm{NE}_{\mathrm{l}}=$ milk $* \mathrm{EV}(\mathrm{EV}=4.6 \mathrm{MJ} / \mathrm{kg})$ \\
\hline 2.7 & REM & $\begin{array}{l}\mathrm{REM}=\left[1.123-\left(4.092 * 10^{-3} * \mathrm{DE} \%\right)+(1.126 * 10\right. \\
5 *(\mathrm{DE} \%))]\end{array}$ \\
\hline 2.8 & REG & $\begin{array}{l}\mathrm{REG}=\left[1.164-\left(5.160 * 10^{-3} * \mathrm{DE} \%\right)+(1.308 * 10\right. \\
5 *(\mathrm{DE} \%))]\end{array}$ \\
\hline
\end{tabular}

REM=ratio of net energy available in a diet for maintenance to digestible energy consumed; DE\%=digestible energy expressed as a percentage of gross energy; $\mathrm{REG}=$ ratio of net energy available for growth in a diet to digestible energy consumed; $\mathrm{BW}=$ the average live body weight of the animals in the population $(\mathrm{kg})$; $\mathrm{MW}=$ the mature live 
body weight of an adult female in moderate body condition $(\mathrm{kg})$; WG=the average daily weight gains of the animals in the population $\left(\mathrm{kg} \mathrm{day}^{-1}\right)$

Source: IPCC (2006)

After the values for GE requirement in the equation (2) calculated for each animal category, then values were substituted in the equation (1) above.

\section{Estimation of manure methane emission}

In the developed world, substantial amount of $\mathrm{CH}_{4}$ emissions from manure management associated with confined animal management operations where manure managed in liquid-based systems. However, in the study area there was no confined manure handling practices, since the livestock production system is more of extensive grazing. Therefore, the Tier 1 default values of the livestock grazed on the roughage feeds from Tropical Africa with annual temperature range of the environment $\left(15-25{ }^{\circ} \mathrm{C}\right)$ and feed digestibility of $45-55 \%$ were used to estimate $\mathrm{CH}_{4}$ emission factors of manure from the existing livestock. The default EF values for cattle, sheep, horse and donkey were 1, 0.15, 1.64 and 0.9, respectively (IPCC, 2006).

Therefore, based on the expressions above, the total annual $\mathrm{CH}_{4}$ emissions from enteric fermentation and manure management of the existing livestock were estimated according to IPCC (2006):

$$
\mathrm{CH}_{4}\left(\mathrm{~kg}^{-1} \text { head }^{-1} \text { year }^{-1}\right)=\mathrm{EF} * \mathrm{~N}_{\mathrm{t}}
$$

Where: $\mathrm{CH} 4$ = methane emission from defined livestock type,

$\mathrm{EF}=$ emission factor for the defined livestock population, $\mathrm{kg} \mathrm{CH}_{4}$ head $^{-1} \mathrm{year}^{-1}$,

$\mathrm{Nt}=$ the number of head of the livestock species/category under consideration and t is type of the livestock species or category.

\section{Data Analysis}

The data were analyzed using Statistical Packages for Social Sciences (SPSS) software packages version 20.0 (Morgan et al., 2004). To compare the differences between the wealth group livestock holding, nutrient requirement and methane emission rates: one-way analysis of variance (ANOVA) was used. The One-way ANOVA model used was:

$\mathrm{Yij}=\mu_{\mathrm{i}}+\mathrm{W}_{\mathrm{i}}+\mathrm{e}_{\mathrm{ij}}$

Where: 
$\mathrm{Y}_{\mathrm{ij}}$ is the $\mathrm{j}^{\text {th }}$ observation in the $\mathrm{i}^{\text {th }}$ wealth group;

$\mu_{\mathrm{i}}$ is the common effect for the whole wealth groups,

$\mathrm{W}_{\mathrm{i}}$ is the effect of the $\mathrm{i}^{\text {th }}$ wealth group and $\mathrm{e}_{\mathrm{ij}}$ is the random error associated with the $\mathrm{j}^{\text {th }}$ observation in the $\mathrm{i}^{\text {th }}$ wealth groups assumed to be normally and independently distributed.

The tests were done at 95\% level of confidence $(\alpha=0.05)$ and Turkey's' HSD mean comparison procedure was used to test mean differences.

\section{RESULT AND DISCUSSION}

\section{Household Livestock Holding}

Table 2 depicts mean livestock species and herd categories of the HHs in TLU. The mean total cattle, cow, ox and heifer were significantly $(\mathrm{P}<0.001)$ different between the wealth groups. The mean steer and sheep TLU holding was significantly $(\mathrm{P}<0.01)$ different between better and the other groups while horse and donkey were significantly $(\mathrm{P}<0.001)$ higher for the better wealth HHs. From the total livestock owned by the wealth groups, cattle accounted for 80 to $90 \%$ at $\mathrm{HH}$ level while from the cattle herd structure, the oxen $(48.75 \%)$ followed by cows $(31.03 \%)$. The more number of TLU possessed by the better wealth HHs accounted to the difference in grazing land owned. Cattle were the dominant stock, while the number of oxen still pronounced within the herd across the wealth groups (Table 2) since cattle predominantly used for draught power in the area like the other mixed farming areas of Ethiopia (Daba et al., 2009). In addition, sheep rose for the immediate cash need and meat while equines used for transportation of farm inputs and products, pulling cart and riding. Comparable reports (Assefa et al., 2014; Birhan and Adugna, 2014) were confirmed why livestock raised in the mixed farming system of the country. The livestock herd proportions indicated that the better HHs had raised more number of diversified herd categories compared to the other wealth groups (Table 2). The observed difference between the wealth groups help to validate the diversity when planning a sustainable livestock development programs (McDermott et al., 2010). The small number of steers reported compared to other herd categories was because of early age sale to manage feed shortage. 
Table 2. Livestock herd structure (TLU per $\mathrm{HH}$ ) in the mixed farming areas of Bale highlands

\begin{tabular}{|c|c|c|c|c|c|c|}
\hline \multirow{3}{*}{$\begin{array}{l}\text { Livestock } \\
\text { category }\end{array}$} & \multirow{3}{*}{$\begin{array}{c}\text { Herd } \\
\text { structure }\end{array}$} & \multicolumn{3}{|c|}{ Wealth group } & \multirow{2}{*}{$\begin{array}{c}\text { Overall } \\
\text { mean (156) }\end{array}$} & \multirow[t]{3}{*}{$P$ value } \\
\hline & & Better (40) & Medium(85) & Low (31) & & \\
\hline & & Mean(SE) & Mean(SE) & $\operatorname{Mean}(\mathrm{SE})$ & Mean(SE) & \\
\hline \multirow[t]{6}{*}{ Cattle } & Total & $13.99(0.44)^{\mathrm{a}}$ & $7.59(0.27)^{\mathrm{b}}$ & $3.48(0.19)^{\mathrm{c}}$ & $8.41(0.35)$ & 0.000 \\
\hline & Cow & $4.78(0.1)^{\mathrm{a}}$ & $2.22(0.11)^{b}$ & $0.88(0.10)^{\mathrm{c}}$ & $2.61(0.13)$ & 0.000 \\
\hline & Ox & $6.23(0.23)^{\mathrm{a}}$ & $3.88(0.13)^{\mathrm{b}}$ & $1.95(0.09)^{\mathrm{c}}$ & $4.10(0.15)$ & 0.000 \\
\hline & Heifer & $1.34(0.12)^{\mathrm{a}}$ & $0.69(0.05)^{\mathrm{b}}$ & $0.21(0.06)^{\mathrm{c}}$ & $0.76(0.05)$ & 0.000 \\
\hline & Steer & $1.38(0.16)^{\mathrm{a}}$ & $0.43(0.06)^{b}$ & $0.15(0.06)^{b}$ & $0.62(0.06)$ & 0.007 \\
\hline & Calf & $0.59(0.04)^{\mathrm{a}}$ & $0.32(0.02)^{\mathrm{ab}}$ & $0.14(0.02)^{b}$ & $0.36(0.02)$ & 0.021 \\
\hline Sheep & & $0.53(0.08)^{\mathrm{a}}$ & $0.28(0.04)^{\mathrm{ab}}$ & $0.14(0.04)^{b}$ & $0.31(0.03)$ & 0.010 \\
\hline Horse & & $0.98(0.06)^{\mathrm{a}}$ & $0.32(0.04)^{\mathrm{b}}$ & $0.15(0.06)^{\mathrm{b}}$ & $0.46(0.04)$ & 0.046 \\
\hline Donkey & & $1.22(0.05)^{\mathrm{a}}$ & $0.65(0.04)^{b}$ & $0.30(0.06)^{\mathrm{b}}$ & $0.73(0.04)$ & 0.016 \\
\hline Cattle (\%) & & 81.86 & 85.96 & 89.92 & 84.25 & \\
\hline
\end{tabular}

$a b c=$ means within the same row with different superscripts are significantly different

\section{Livestock Manure Management}

Homestead manure management; collection from the place where the animal drops it (more often

Kraal), family house and backyard during night can be used either for dung cake (fuel) and/or organic fertilizer (Figure 1), and other minor uses which are not mentioned here. Numbers depicted that cattle manure collected $100 \%$ while that of equine was $88.5 \%$. However, there were differences in that of manure made into dung cake from cattle $(78.8 \%)$ and equine (25.0\%). Whereas, manure used as farm yard fertilizer from all stocks looks similar, where more attention given to the use of manure as fuel. On the other hand, manure dropped in the grazing areas during dry period collected and used as fuel while the remained dung used to maintain the ecosystem via supplying organic fertilizer to the soil (IPCC, 2006). Similarly, Onduru et al. (2008) reported that in Kenya, animals graze in the fields during the day adds a potential in situ manure utilization of the soil fertility. In general, the present result implies that farmers are not much valued manure as organic fertilizer and biogas generation compared to the current practice (fuel) which has environmental effect. 


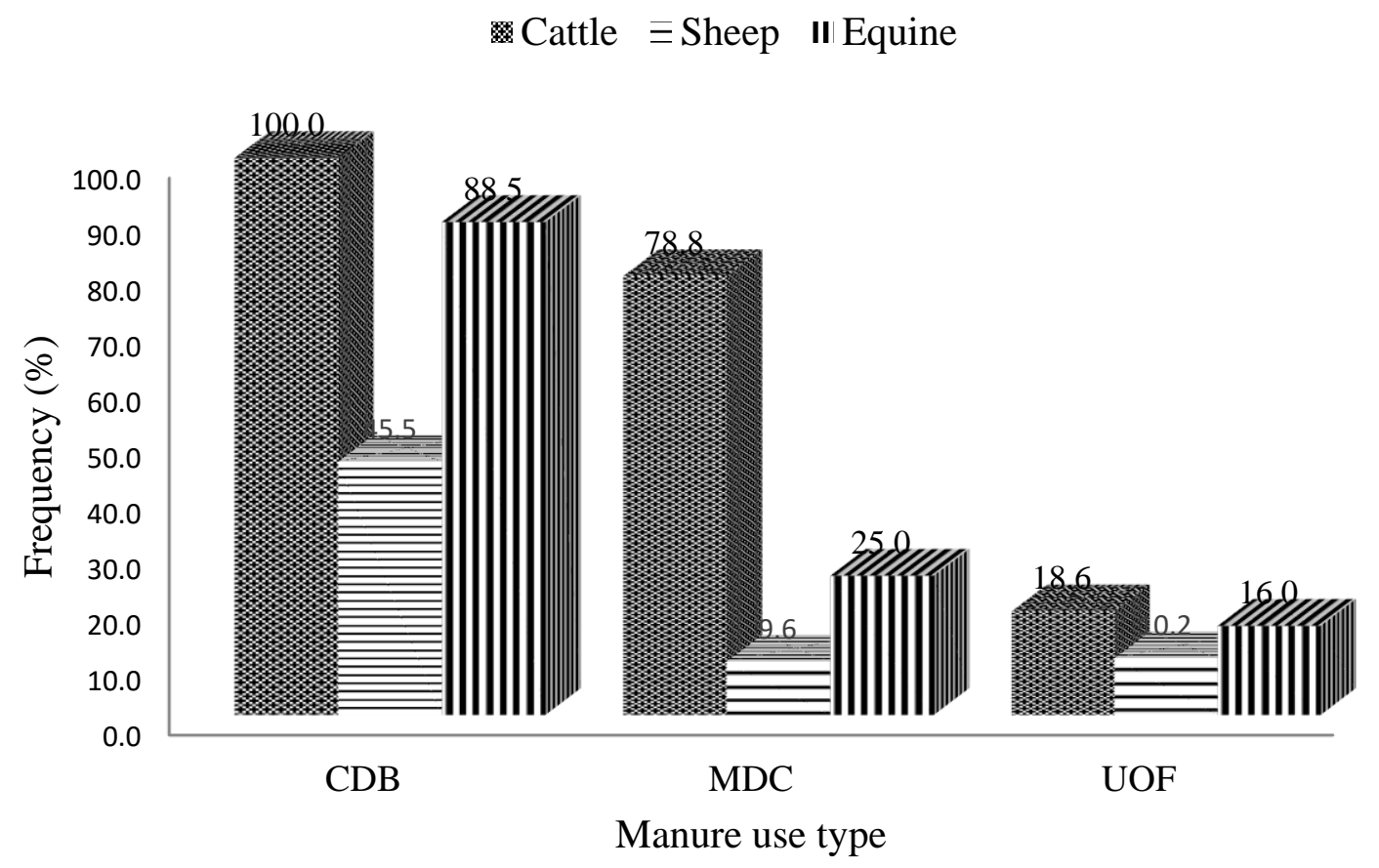

$\mathrm{CDB}=$ collected on daily basis $; \mathrm{MDC}=$ made into dung cake $\mathrm{UOF}=$ use as organic fertilizer

Figure 1. Manure collection and utilization type at household level in the mixed farming areas of Bale highlands

\section{Estimated Livestock Methane Emissions}

Table 3 presents enteric $\mathrm{CH}_{4}(\mathrm{~kg})$ emission factors and emission rates of different livestock categories of the wealth groups in the study area. The estimated enteric $\mathrm{CH}_{4} \mathrm{EF}$ from mature cattle was significantly $(\mathrm{P}<0.001)$ lower for the better wealth $\mathrm{HHs}$ compared to other groups while EF of growing cattle was significant $(\mathrm{P}<0.05)$ between better and other wealth groups. Whereas, EFs for sheep greater than one year, sheep to one year, horse and donkey were not significantly $(\mathrm{P}<0.05)$ different between the wealth groups. The enteric $\mathrm{CH}_{4}$ emission rates from the livestock categories were significantly different $(\mathrm{P}<0.001)$ between the wealth groups. The overall mean estimated enteric $\mathrm{CH}_{4}$ emission from mature cattle higher followed by growing cattle. The total enteric $\mathrm{CH}_{4}$ emission at $\mathrm{HH}$ level of the wealth groups were more pronounced from the better group HHs compared to medium and the low group HHs.

The study revealed enteric $\mathrm{CH}_{4}$ emission from mature and growing cattle were very high $(91.52 \%)$ compared to sheep and equines which has credited to the more number of cattle herds 
at $\mathrm{HH}$ level was comparable to the $84 \%$ livestock emission from cattle reported by FDRE-CRGE (2011). The present enteric $\mathrm{CH}_{4} \mathrm{EFs}$ for cattle and sheep categories were in close agreement with the IPCC values from developing countries in African, Middle East and other tropical regions livestock EFs under similar production system and animal functions (IPCC, 2006, Herrero et al., 2008). However, EF from mature cattle was higher than an average figure of $32 \mathrm{~kg} \mathrm{CH}_{4}$ per TLU per year for African ruminants (Herrero et al. 2008). The emission rates from enteric $\mathrm{CH}_{4}$ production aligned with higher EFs, large number of animals and complex herd structure possessed by the better group. Likewise, Herrero et al. (2013), Hristov et al. (2013) and Teenstra et al. (2015) reported that from the total $\mathrm{CH}_{4}$ emission, $90 \%$ is from enteric fermentation while mixed system produce the bulk of emissions from ruminants. On the other hand, the estimated low enteric $\mathrm{CH}_{4}$ emission from herds of the low wealth group might be due to less number of animals possessed and similar condition where reported by Singh et al. (2012).

The other concern is that when roughage feeds intake increased beyond maintenance requirement for working animals; $\mathrm{CH}_{4}$ escalates from the additional feed ingested to generate more energy for work. The scenario recalls for efficient use of draught power or mechanized cultivation to curb $\mathrm{CH}_{4}$ emission from extra GEI which is also accompanied by lose of energy whenever feed energy converted to $\mathrm{CH}_{4}$. Singh et al. (2012) justified that enteric $\mathrm{CH}_{4}$ from working males $(53.6 \%)$ is more than female $(46.4 \%)$ in India while Dlamini and Dube (2014) reported animals with a higher feed intake have more $\mathrm{CH}_{4}$ emission. Hence, herding animals of better productivity performance with the low enteric emission rate per product or services rendered is a likely solution to lessen livestock $\mathrm{CH}_{4}$ emissions. On the other hand, increasing roughage feeds digestibility was an expedient way to reduce enteric $\mathrm{CH}_{4}$ emissions with accompanied minimized animal number and increased product. Therefore, the present report of enteric $\mathrm{CH}_{4}$ production of the existing livestock herd categories of the prevailing feeding regime presents ample scopes to abate $\mathrm{CH}_{4}$ emission through appropriate feeding interventions. 
Table 3. Household level estimated enteric $\mathrm{CH}_{4}$ emissions in the mixed farming areas of Bale highlands

\begin{tabular}{|c|c|c|c|c|c|c|c|}
\hline \multirow[t]{3}{*}{ Livestock category } & \multicolumn{3}{|c|}{ Wealth groups } & \multirow{2}{*}{$\begin{array}{c}\text { Overall mean } \\
(156)\end{array}$} & \multirow{3}{*}{$\begin{array}{c}\mathrm{P} \\
\text { value }\end{array}$} & \multirow{3}{*}{$\begin{array}{l}\text { Total } \\
\text { CH4 }\end{array}$} & \multirow[t]{3}{*}{$\%$} \\
\hline & Better (40) & Medium (85) & Low (31) & & & & \\
\hline & Mean (SE) & Mean (SE) & Mean (SE) & Mean (SE) & & & \\
\hline \multicolumn{8}{|c|}{ Emission Factors $\left(\mathrm{kg}^{-1} \mathrm{head}^{-1}\right.$ year $)$} \\
\hline Mature cattle** & $39.40(0.0)^{\mathrm{b}}$ & $40.34(0.0)^{\mathrm{a}}$ & $40.20(0.02)^{\mathrm{a}}$ & $40.08(0.03)$ & 0.000 & & \\
\hline Growing cattle* & $20.02(0.0)^{\mathrm{b}}$ & $20.56(0.0)^{\mathrm{a}}$ & $20.51(0.0)^{\mathrm{a}}$ & $20.42(0.02)$ & 0.025 & & \\
\hline Sheep $>1$ year & $3.48(0.0)$ & $3.55(0.0)$ & $3.54(0.0)$ & $3.53(0.0)$ & 0.070 & & \\
\hline Sheep up to 1 year & $1.74(0.0)$ & $1.79(0.0)$ & $1.78(0.0)$ & $1.77(1.52)$ & 0.202 & & \\
\hline Horse & $18.00(0.0)$ & $18.00(0.0)$ & $18.00(0.0)$ & $18.00(0.0)$ & 0.972 & & \\
\hline Donkey & $10.00(0.0)$ & $10.00(0.0)$ & $10.00(0.0)$ & $10.00(0.0)$ & 0.994 & & \\
\hline \multicolumn{8}{|l|}{ Emission rate $\left(\mathrm{kg}^{-1}\right.$ year $)$} \\
\hline Mature cattle & $459.99(13.19)^{\mathrm{a}}$ & $252.96(8.66)^{\mathrm{b}}$ & $114.27(5.31)^{\mathrm{c}}$ & $278.48(11.22)$ & 0.000 & 827.22 & 69.78 \\
\hline Growing cattle & $153.61(9.63)^{\mathrm{a}}$ & $75.64(4.35)^{\mathrm{b}}$ & $28.45(3.88)^{\mathrm{c}}$ & $86.25(4.93)$ & 0.000 & 257.70 & 21.74 \\
\hline Sheep $>1$ year & $8.96(1.43)^{\mathrm{a}}$ & $5.39(1.06)^{\mathrm{b}}$ & $2.63(0.85)^{\mathrm{c}}$ & $5.76(0.73)$ & 0.000 & 16.98 & 1.43 \\
\hline Sheep up to 1 year & $4.39(0.74)^{\mathrm{a}}$ & $2.67(0.52)^{\mathrm{b}}$ & $1.03(0.35)^{\mathrm{c}}$ & $2.79(0.36)$ & 0.000 & 8.09 & 0.68 \\
\hline Horse & $22.05(1.36)^{\mathrm{a}}$ & $7.62(0.97)^{\mathrm{b}}$ & $3.48(1.29)^{\mathrm{b}}$ & $10.50(0.88)$ & 0.000 & 33.15 & 2.79 \\
\hline Donkey & $23.25(0.97)^{\mathrm{a}}$ & $12.94(0.73)^{b}$ & $6.13(1.19)^{\mathrm{c}}$ & $14.23(0.70)$ & 0.000 & 42.32 & 3.57 \\
\hline Total $\mathrm{CH}_{4}$ & 672.25 & 357.22 & 155.99 & 398.01 & & 1185.46 & \\
\hline HH \% & 56.71 & 30.13 & 13.16 & & & & \\
\hline
\end{tabular}

$a b c=$ Means within the same row with different superscripts are significantly different $\mathrm{HH}=$ household; $* *=280 \mathrm{~kg}$ average live weight; $*=200 \mathrm{~kg}$ average live weight

\section{Manure Methane Emission}

The estimated $\mathrm{CH}_{4}$ emission from manure handling practices in the study area wealth groups' livestock is presented in Table 4. There were a significant $(\mathrm{P}<0.001)$ difference between the three wealth groups manure $\mathrm{CH}_{4}$ emissions from cattle. But, emission from donkey was significantly $(\mathrm{P}<0.05)$ higher for better groups. Similarly, $\mathrm{CH}_{4}$ emission from sheep was different $(\mathrm{P}<0.01)$ between better and low groups. In the mixed farming areas of Ethiopia; manure has been used for fuel and sometimes as organic fertilizer on farm lands which is a similar practice to the study area. In the study area, manure was collected mainly from Kraal and made into dungcake in open environment (Figure 1). When manure handled in such a way, the potential $\mathrm{CH}_{4}$ emission was less significant due to aerobic condition of the open environment. Likewise, when manure utilized in a dry form such as in stacks or dry lots for fertilizer on fields, it tends to decompose under aerobic conditions and insignificant amounts of $\mathrm{CH}_{4}$ produced (Steinfeld et al., 2006; 
Hristov et al., 2013). The manure from kraal was collected and made into dung cake on the dry ground/soil under the sun and used as fuel. Though small amount of $\mathrm{CH}_{4}$ produced from manure under the existing traditional husbandry practice, it is not a sound problem of $\mathrm{CH}_{4}$ effect compared to the enteric emissions observed from the existing livestock. However, the increase in the herd size might lead to the increased manure $\mathrm{CH}_{4}$ emission particularly when manure stored for long period of time under anaerobic condition at farm level.

Table 4. Household level estimated manure $\mathrm{CH}_{4}$ emission in the mixed farming areas of Bale highlands

\begin{tabular}{|c|c|c|c|c|c|c|c|}
\hline \multirow{4}{*}{$\begin{array}{l}\text { Livestock } \\
\text { category }\end{array}$} & \multicolumn{3}{|c|}{ Wealth groups } & \multirow{2}{*}{$\begin{array}{c}\text { Overall mean } \\
(156)\end{array}$} & \multirow[t]{4}{*}{$P$ value } & \multirow{4}{*}{$\begin{array}{c}\text { Total } \\
\mathrm{CH}_{4}\left(\mathrm{~kg}^{-}\right. \\
\left.{ }^{1} \text { year }\right)\end{array}$} & \multirow{4}{*}{$\begin{array}{c}\text { Total } \\
\text { emission } \\
(\%)\end{array}$} \\
\hline & Better (40) & $\begin{array}{c}\text { Medium } \\
\text { (85) }\end{array}$ & Low (31) & & & & \\
\hline & Mean (SE) & Mean (SE) & Mean (SE) & Mean (SE) & & & \\
\hline & $\begin{array}{l}\mathrm{CH}_{4}\left(\mathrm{~kg}^{-}\right. \\
\left.{ }^{1} \text { year }\right)\end{array}$ & $\begin{array}{l}\mathrm{CH}_{4}\left(\mathrm{~kg}^{-}\right. \\
\left.{ }^{1} \text { year }\right)\end{array}$ & $\begin{array}{l}\mathrm{CH}_{4}\left(\mathrm{~kg}^{-}\right. \\
\left.{ }_{\text {1 }} \text { year }\right)\end{array}$ & $\mathrm{CH}_{4}\left(\mathrm{~kg}^{-1}\right.$ year $)$ & & & \\
\hline Cattle & $19.33(0.65)^{\mathrm{a}}$ & $9.95(0.38)^{\mathrm{b}}$ & $4.23(0.28)^{\mathrm{c}}$ & $11.22(0.49)$ & 0.000 & 33.51 & 80.28 \\
\hline Sheep & $0.77(0.12)^{\mathrm{a}}$ & $0.45(0.09)^{\mathrm{ab}}$ & $0.19(0.06)^{\mathrm{b}}$ & $0.48(0.06)$ & 0.033 & 1.41 & 3.38 \\
\hline Horse & $2.01(0.12)^{\mathrm{a}}$ & $0.69(0.09)^{\mathrm{b}}$ & $0.32(0.12)^{\mathrm{b}}$ & $0.96(0.08)$ & 0.016 & 3.02 & 7.24 \\
\hline Donkey & $2.09(0.09)^{\mathrm{a}}$ & $1.16(0.06)^{b}$ & $0.55(0.11)^{\mathrm{c}}$ & $1.28(0.06)$ & 0.012 & 3.80 & 9.10 \\
\hline HH total & 24.20 & 12.25 & 5.29 & 13.94 & & 41.74 & \\
\hline HH share(\%) & 57.98 & 29.35 & 12.67 & & & & \\
\hline
\end{tabular}

$a b c=$ Means within the same row with different superscripts are significantly different; $\mathrm{HH}=$ household

Farm level livestock emitted $\mathrm{CH}_{4}\left(\mathrm{~kg}^{-1}\right.$ head ${ }^{-1}$ year$)$ and its equivalent global warming potential in the study districts is indicated in Table 5. The large enteric $\mathrm{CH}_{4}$ emission from cattle in the study area wealth group HHs and total livestock emission of the districts had a higher GWP compared to the other animals raised by the farmers. Similarly, farm level $\mathrm{CH}_{4}$ emission in the study area was very small amount compared to the total emission from the total study districts livestock of the mixed farming system. While livestock contributions to the socio-cultural and sustainable livelihoods are substantial, their influence on climate change cannot be overlooked. The relevant studies reported that the likely increase of $\mathrm{CH}_{4}$ emissions in the coming decades because of the ever increasing demand for livestock products (IPCC, 2006; FAO, 2013). Therefore, livestock sector become an attractive target of GHG reduction campaigns. From this sector, a small change per animal emission could result in large changes in total GHG emissions due to large livestock population broadly in Ethiopia and in the study area in particular. The overall, estimated $\mathrm{CH}_{4}$ 
emission has prominent effect on climate change due to its high global warming potential (34 times that of $\mathrm{CO}_{2}$ ) when the concentration increased in the atmosphere (IPCC, 2014). In general, the cumulative effect of $\mathrm{CH}_{4}$ emission was a sound problem of the highland mixed farming areas compared to the farm level relative small amount of emission in the study area due to its higher GWP (Table 5). Therefore, a key starting point to assess mitigation of the livestock emissions were to understand baseline level of $\mathrm{CH}_{4}$ emission associated with different livestock categories, major GHGs emitted, the main sources and the farming community wealth differences under the prevailing livestock production system.

Table 5. Livestock emitted $\mathrm{CH}_{4}$ global warming potential in the mixed farming areas of Bale highlands

\begin{tabular}{|c|c|c|c|c|c|c|}
\hline \multirow{2}{*}{\multicolumn{2}{|c|}{$\begin{array}{c}\text { Livestock } \\
\text { species }\end{array}$}} & \multicolumn{2}{|c|}{ Farm level total emission } & \multicolumn{3}{|c|}{ Study districts total emission } \\
\hline & & $\mathrm{CH}_{4}\left(\mathrm{~kg}^{-1}\right.$ year $\left.)\right)$ & $\begin{array}{c}* \mathrm{CO}_{2} \text {-e GWP } \\
(\mathrm{MT})\end{array}$ & $\begin{array}{l}\text { Livestock } \\
\text { (head) }\end{array}$ & $\begin{array}{c}\mathrm{CH}_{4}(\mathrm{~kg} / \text { year }) \\
(` 000)\end{array}$ & $\begin{array}{c}\mathrm{CO}_{2} \text {-e GWP } \\
(\mathrm{MT})\end{array}$ \\
\hline 1 & Cattle & 375.95 & $1.28 \times 10^{-6}$ & 388334.0 & 145994.2 & 4.96 \\
\hline 2 & Sheep & 9.03 & $3.07 \times 10^{-7}$ & 49815.0 & 449.8 & 0.015 \\
\hline 3 & Horse & 11.46 & $3.91 \times 10^{-7}$ & 23080.0 & 264.5 & 0.089 \\
\hline & Donkey & 15.51 & $1.55 \times 10^{-7}$ & 23368.0 & 362.4 & 0.012 \\
\hline \multicolumn{2}{|c|}{ Total } & 411.95 & $1.40 \times 10^{-5}$ & & 147070.9 & 5.01 \\
\hline
\end{tabular}

\section{CONCLUSSION}

From this study, it can be concluded that livestock production is a hub sector that plays crucial role to the smallholder's livelihood in the study area. Livestock farming contribute to climate attributes variation in different ways in course of production due to perceived traditional husbandry practices, species raised (large number of ruminants) and poor resource allocation that increase livestock contribution to climate change through hampering animal productivity and enhancing $\mathrm{CH}_{4}$ emissions. In the area, mature and growing cattle emitted $69.78 \%$ and $21.74 \%$ enteric $\mathrm{CH} 4$, respectively at farm level. Though sheep and equine emitted low enteric $\mathrm{CH}_{4}$, compared to cattle, they lack some products and services provided by cattle to the households. Hence, emission from study area livestock could be linked to species type, population size, and low productivity which cause extra emission without obtaining valuable product. This tends to increase $\mathrm{CH}_{4}$ emissions from the sector that has a global warming potential of 34 times that of $\mathrm{CO}_{2}$ in the atmosphere and the total $\mathrm{CH}_{4}$ emission from the study area total livestock population 
has an implication to global warming at lower extent compared to tropical African's livestock $\mathrm{CH}_{4}$ emission rates.

\section{Acknowledgements}

The authors like to acknowledge Addis Ababa University and Madda Walabu University for financial support. The authors like to thank staf of the study area districts agriculture and rural development offices, development agents who assisted in data collection and farmers of the study area for their cooperation during interview.

\section{REFERENCES}

Arsham, H. (2007): Questionnaire design and survey sampling. Retrieved 28, December 2015 from, http://home.ubalt.edu/ntsbarsh/stat-data/surveys.htm.

Assefa F.T., Animute G., Mekasha Y. and Urge M. (2014): Assessment of the feeding potential and utilization of Erythrinaburana and Casimiroaedulis in Eastern Hararghe Zone of Ethiopia. Livestock Research for Rural Development 26(5).

Birhan M. and Adugna T. (2014): Livestock feed resources assessment, constraints and improvement strategies in Ethiopia. Middle-East J. Sci. Res., 21(4): 616-622.

BoFED (2012): Socio-Economic profile (unpublished). Bureau of Finance and Economy Development: Department of Planning and Budget Annual report, Bale Zone.

CDR (Community Development Research) (2011): Ethiopia; methane emissions from agricultural wastes country resource assessment. Global Methane Initiative. CDR, October 2011.

Chibsa T. and Ta'a A. (2009): Assessment of soil organic matter under four land use systems in Bale highlands, Southeast Ethiopia: Soil Organic matter contents in four land use systems (Forestland, Grassland, Fallow land and Cultivated land). World Appl. Sci. J., 6(9): 1231-1246.

CSA (Central Statistical Agency of the Federal Democratic Republic of Ethiopia) (2016): Agricultural sample survey: Livestock and livestock characteristics. CSA, Bulletin 583, Volume II, June 2016, Addis Ababa, Ethiopia.

Daba T., Kitaw G., Kehaliwu A., Bediye S., Fekadu D, Hatew D. and Ayalew L. (2009): Feed resource status, livestock feeding and management in the central highlands of Ethiopia. Pp. 203226. Climate change, livestock and people: Challenges, opportunities, and the way forward. Proceedings of the $17^{\text {th }}$ Annual conference of the Ethiopian Society of Animal Production (ESAP) held in Addis Ababa, September 24 to 26, 2009, Addis Ababa, Ethiopia.

Deressa T.T. 2010: Assessment of the vulnerability of Ethiopian agriculture to climate change and farmers' adaptation strategies. PhD Dissertation Submitted to Department of Agricultural Economics, Extension and Rural Development, Faculty of Natural and Agricultural Sciences, University of Pretoria, 113p. 
Dlamini A.M. and Dube M.A. (2014): Contribution of animal agriculture to greenhouse gases production in Swaziland. American Journal of Climate Change, 3: 253-260.

Eba B.T. (2012): Study of smallholder farms livestock feed sourcing and feeding strategies and their implication on livestock water productivity in mixed crop-livestock systems in the highlands of the Blue Nile basin, Ethiopia. MSc Thesis Submitted to Department of Animal Sciences, School of Graduate Studies, Haramaya University, 121p.

FAO (Food and Agriculture Organization of the United Nations) (2013): Coping with climate change; the importance of genetic resources for food security. Commission on genetic resources for food and agriculture. Food and Agriculture Organization of the United Nations. Retrieved June 9, 2015 from, www.fao.org/nr/cgrfa.

FDRE-CRGE (Federal Democratic Republic of Ethiopia-Climate Resilient Green Economy) (2011): Ethiopia's Climate-Resilient Green Economy: Green economy strategy. Addis Ababa, Ethiopia.

Gebremedhin B., Hirpha A. and Berhe K. (2009): Feed marketing in Ethiopia: results of rapid market appraisal. Improving Productivity and Market Success (IPMS) of Ethiopian farmers', Working Paper 15. International Livestock Research Institute, Nairobi, Kenya.

Gryseels G. (1988): Role of livestock on a mixed smallholder farms in the Woredas near DebreBerhan. PhD Dissertation. Agricultural University of Wageningen, The Netherlands, 249p.

Herrero M., Havlík P., Valin H., Notenbaert A., Rufino M.C., Thornton K.P., Blümmel M., Weiss F., Grace D. and Obersteiner M. (2013): Biomass use, production, feed efficiencies and greenhouse gas emissions from global livestock systems. PNAS, 110(52): 20888-20893.

Herrero M., Thornton P.K., Kruska R., and Reid R.S. (2008): Systems dynamics and the spatial distribution of methane emissions from African domestic ruminants to 2030. Agriculture, Ecosystems and Environment, 126(2):122-137.

Hristov A.N., Oh J., Lee C., Meinen R., Montes F., Ott T., Firkins J., Rotz A., Dell C., Adesogan A., Yang W., Tricarico J., Kebreab E., Waghorn G, Dijkstra J. and Oosting S. (2013): Mitigation of greenhouse gas emissions in livestock production. A review of technical options for non- $\mathrm{CO}_{2}$ emissions. Edited by P. J. Gerber, Benjamin H., Harinder P. and S. Makkar. FAO Animal Production and Health Paper No. 177. Rome, Italy.

IGAD (Intergovernmental Authority on Development) (2011): The contribution of livestock Ethiopian to economy Part II. IGAD Livestock Policy Initiative Working Paper No. 02-11. Addis Ababa, Ethiopia, 44p.

IPCC (Intergovernmental Panel on Climate Change) (2014): Climate change 2014: Synthesis report. Contribution of working groups I, II and III to the fifth assessment report of the IPCC, Core writing team, Geneva, Switzerland, 151p.

IPCC (2006): Emissions from livestock and manure management. In: 2006 IPCC guidelines for national greenhouse gas inventories. Agriculture, Forestry and Other Land Use, 4: 10.1-10.87. 
Jahnke H.E. (1982): Livestock production systems and livestock development in tropical Africa. Kieler Wissenschafsverlag, VAUK.

Jo N., Kim J. and Seo S. (2015): Estimation of methane emission factor for enteric fermentation of growing-finishing Hanwoo steers using the IPCC Tier 2 approach. PeerJ PrePrints. https://dx.doi.org/10.7287/peerj.preprints.1285v1.

Kearl L.C. (1982): Nutrient requirement of ruminants in developing countries international feed stuffs institute, Utah Agricultural Experiment Station, Utah State University, Longman. USA, 389p.

McDermott J.J., Staal S.J., Freeman H.A., Herrero M. and Van de Steeg J.A. (2010): Sustaining intensification of smallholder livestock systems in the tropics. Livestock Science, 1-15 doi:10.1016/j.livsci.2010.02.014.

Morgan G.A., Leech N.L., Gloeckner G.W. and Barret A.C. (2004): SPSS for Introductory Statistics use and Interpretation ( $2^{\text {nd }}$ eds). Lawrence Erlbaum Associates Publishers, London.

Onduru D.D., Snijders P., Muchena F.N., Wouters B., De Jager A., Gachimbi L. and Gachini G.N. (2008): Manure and soil fertility management in Sub-humid and Semi-arid farming Systems of SubSaharan Africa: Experiences from Kenya. Int. J. Agric. Res., 3: 166-187.

Scholtz M.M., Steyn Y., Van Marle-Köster E. and Theron H.E. (2012): Improved production efficiency in cattle to reduce their carbon footprint for beef production. S. Afr. J. Anim. Sci., 42(5): 450-453.

Silvia S. and Deborah K. (2012): Measurement and mitigation of greenhouse gases in African livestock systems: building capability to meet the challenge, Workshop report. Nairobi, Kenya.

Singh S., Kushwaha B.P., Nag S.K., Bhattacharya S., Gupta P.K., Mishra A.K. and Singh A. (2012): Assessment of enteric methane emission of Indian livestock in different agro-ecological regions. Current Science, 102(7): 1017-1027.

Steinfeld H., Gerber P., Wassenaar T., Castel V., Rosales M. and Haan C. (2006): Livestock's long shadow: Environmental issues and options. Food and Agriculture Organization of the United Nations (FAO), Rome, Italy. pp. 97.

Teenstra E., Buisonjé D., Ndambi A. and Pelster D. (2015): Manure management in the (Subtropics; training manual for extension workers. Wageningen, UR (University and Research centre) Livestock Research, Livestock Research Report 919. Wageningen, The Netherlands. 